\title{
Geografske zasnove sonaravnega načrtovanja regionalnega napredka Zasavske regije
}

\author{
Dušan Plut \\ Dr., Oddelek za geografijo, Filozofska fakulteta, Univerze v Ljubljani, \\ Aškerčeva 2, 1000 Ljubljana, Slovenija \\ e-mail: dusan.plut@ff.uni-lj.si
}

\section{Izvleček}

Geografske zasnove načrtovanja regionalnega napredka in posegov v geografsko okolje izhajajo iz predpostavk koncepta trajnega prilagajanja antropogenih sprememb v pokrajini svojstvenim zmogljivostim in omejitvam pokrajinotvornih sestavin. $\checkmark$ pokrajinsko degradirani Zasavski regiji je izboljšanje kakovosti okolja (kurativni ukrepi) in regionalni gospodarski napredek v okviru nosilnih zmogljivosti okolja in prostora (preventivni ukrepi) temeljni razvojno-okoljsko zasnovan cilj razvojne strategije.

Ključne besede: Sonaravni regionalni napredek, geografske zasnove, onesnaženost okolja, izboljšanje kakovosti okolja, Zasavska regija

\section{Geographical Baselines of Sustainable Planning the Regional Development of Zasavje Region}

\begin{abstract}
Geographical baselines of planning the regional development and interventions into the geographical environment derive from the premises of the concept of permanent adjusting the anthropogenic changes in the landscape to specific capacities and limitations of landscape-forming components. In the landscape-degraded region of Zasavje the improvement of environmental quality (curative measures) and regional economic progress within the scope of carrying capacities and space (preventative measures) are the primary, developmentaly-environmentally devised goal of developmental strategy.
\end{abstract}

Key words: Sustainable regional development; Geographical elements; Environmental pollution; Improvement of environmental quality; Zasavje region 


\section{UVOD}

Gospodarska uspešnost regije in kakovost življenja je zasnovana na razvojnem potencialu. Če vsi ključni regionalni dejavniki za razvoj (endogeni faktorji), niso izoblikovani in na razpolago $\mathrm{v}$ dovolj veliki količini, predstavljajo ozko grlo za regionalni razvoj. Stanje okolja in njegovih sestavin, zaloge in prilivi naravnih virov, stopnja njihove izčrpanosti, razpoložljivost prostora so t.i. nemobilni dejavniki endogenega regionalnega razvoja. Pomemben faktor za pritegnitev novih dejavnosti na določeno območje je kvaliteta življenja, ki vključuje tudi kakovost bivalnega okolja in naravnih virov. Naravne dobrine prst, vodo, zrak, rastline in živalstvo je potrebno v regiji tako uporabljati, da bodo posamezno in kot celota lahko trajnostno opravljale svoje naloge naravnih pogojev za kakovostno življenje (Landschaftsrahmenplan fuer..., 1989; Pečar, Farič, 2001). Osnovo predstavlja endogeni potencial regije, torej skupne razvojne možnosti, ki do sedaj niso bile oziroma so bile premalo uporabljene (Foissner, 2000).

Vključevanje varovalnih načel $\mathrm{v}$ usmerjanje regionalnega razvoja bo uspešno le v primeru, da se bo okolje obravnavalo kot večplastni sistem, ki hkrati opravlja več funkcij (Environment in the..., 1999). Načelo sonaravnosti v geografsko zasnovano načrtovanje rabe okoljskih virov regije vnaša upoštevanje principov regeneracije (obnovljivi viri), nevtralizacije (zmogljivost okolja glede obremenjevanja) in substitucije (povečana raba obnovljivih virov). Sonaravni regionalni napredek je trajni gospodarski, infrastrukturni in poselitveni razvoj $\mathrm{v}$ okviru regionalne nosilne zmogljivosti okolja (sestavin), naravnih virov in prostora.

\section{GEOGRAFSKE ZASNOVE RAZVOJNO- VAROVALNEGA RAZVOJA ZASAVSKE REGIJE}

Zasavska regija za potrebe RRP obsega občine Hrastnik, Litijo (pred izločitvijo Šmartnega pri Litiji kot novo ustanovljene občine), Radeče, Trbovlje in Zagorje. Površina regije znaša $643 \mathrm{~km}^{2}$ oziroma $3,2 \%$ državnega ozemlja. Okoljsko ključne geografske stalnice in spremenljivke regionalnega napredka Zasavske regije izhajajo iz geografske lege, položaja, fizično- in družbeno geografskih potez (Preglednica 1).

V regiji je leta 2000 živelo 70.343 prebivalcev, kar je predstavljalo 3,6 \% prebivalstva Slovenije. Stagnacija in nazadovanje prebivalstva regije je skupna rezultanta gospodarskih, zaposlitvenih, socialnih in okoljskih značilnosti polpreteklega regionalnega razvoja. 
Preglednica 1: Okoljsko ključne geografske stalnice in spremenljivke regionalnega napredka Zasavske regije

\begin{tabular}{|c|c|}
\hline Okoljsko ključne geografske stalnice & Okoljsko ključne geografske spremenljivke \\
\hline $\begin{array}{l}\text { Geografsko prehodna lega: } \\
\text { geomorfološko razgiban predalpski svet }\end{array}$ & $\begin{array}{l}\text { Glavna prometna os (cestna in železniška) po } \\
\text { ozki, praviloma globoko vrezani dolini Save }\end{array}$ \\
\hline $\begin{array}{l}\text { Naravnogeografska dvojnost: } \\
\text { a) višje, pretežno kraško hribovje; } \\
\text { b) prostorsko zelo omejen } \\
\text { dolinsko-kotlinski relief }\end{array}$ & $\begin{array}{l}\text { Poselitvena, gospodarska in infrastrukturna } \\
\text { dvojnost: } \\
\text { a) redko poseljeno, ruralno hribovito } \\
\text { podeželje; } \\
\text { b) gosto poseljeno, policentrično urbanizira- } \\
\text { no, industrijsko, premogovniško } \\
\text { območje stranskih dolin Save in Litijske } \\
\text { kotline }\end{array}$ \\
\hline $\begin{array}{l}\text { Naravni viri: } \\
\text { a) omejitveni dejavniki za kmetijstvo; } \\
\text { b) bogati vodni viri; } \\
\text { c) večja gozdnatost regije (hribovje); } \\
\text { d) rjavi premog; } \\
\text { e) pomanjkanje ravnih zemljišč } \\
\text { (prostora) }\end{array}$ & $\begin{array}{l}\text { Dolgotrajna raba rjavega premoga } \\
\text { (TE Trbovlje), zgodnja, intenzivna industriali- } \\
\text { zacija in zaostajanje v razvojni in okoljski } \\
\text { prenovi }\end{array}$ \\
\hline $\begin{array}{l}\text { Zmogljivost okolja: } \\
\text { a) velika zračna občutljivost dolin in } \\
\text { Litijske kotline; } \\
\text { b) velika vodnoekološka občutljivost } \\
\text { zasavskih pritokov Save; } \\
\text { c) velika samočistilna zmogljivost } \\
\text { Save }\end{array}$ & $\begin{array}{l}\text { Dolgotrajna redna ali občasna prekomerna } \\
\text { onesnaženost, stara okoljska bremena, degradi- } \\
\text { ranost pokrajinotvornih sestavin (voda, zrak, } \\
\text { prst, vegetacija, relief) pretežnega dela stran- } \\
\text { skih dolin in bližnjega vzpetega sveta zaradi } \\
\text { premogovništva, energetike, industrije in urba- } \\
\text { nizacije ter cestnega prometa }\end{array}$ \\
\hline
\end{tabular}

Regija se kot celota uvršča med tradicionalna industrijska in rudarsko-energetska območja Slovenije praviloma s staro industrijsko sestavo, nizkim deležem kmečkega prebivalstva, visoko brezposelnostjo in s pokrajinsko degradacijskimi procesi. Celoten regionalni razvoj je temeljno zaznamovala raba osnovnega naravnega vira $v$ regiji-rjavega premoga, energetika in razvoj industrije (Vrišer, 1963). Zlasti v zadnjem desetletju je bilo vse bolj opazno gospodarsko zaostajanje zasavske regije, ki se nahaja $v$ bistveno bolj neugodnem strukturnem položaju kot nekatere druge klasične industrijske regije Slovenije.

Zasavsko imisijsko območje se po številnih regionalnih in občinskih kazalcih onesnaženosti posameznih sestavin okolja in dolgotrajnosti obremenjevanja okolja v obdobju 1975-2000 uvršča med najbolj pokrajinsko degradirane 
regije Slovenije. Obremenjenost okolja z zračnimi emisijami, odpadnimi vodami in različnimi odpadki ter degradiranost reliefa zaradi premogovništva $\mathrm{V}$ številnih območjih presega zelo omejene samočistilne sposobnosti, nosilne zmogljivosti okolja (Špes, 1998; Onesnaženost okolja in...2001, Plut, 2002).

Dolinsko (savski in stranske doline zasavskih vodnih tokov-Medije, Trboveljščica, Bobna in Sopote), kotlinsko območje (Litija-Šmartno) ter južna, višja območja Kumljanskega z obrobjem pa so prekomerno, sezonsko ali občasno tudi kritično onesnažena (Poročilo in ocena... 1998, Onesnaženost okolja in...2001). Naravnogeografske značilnosti regije z veliko reliefno energijo, vzporedniško (Z-V) oblikovano dolino Save in poldnevniško (prečno) potekajočimi stranskimi dolinami savskih pritokov preprečujejo večjo sklenjenost imisijskih območij in tudi oblikovanje koncentričnih obročev različno onesnaženih območij okoli zasavskih mest. Zlasti po obsegu, dolgotrajnosti emisijskih pritiskov, širšemu vplivu in delno tudi po intenzivnosti degradacije zaradi zračnih emisij izstopa imisijsko območje TE Trbovlje. Z gradnjo visokega dimnika se je emisijski pritisk TE Trbovlje na dolinski zasavski ekosistem sicer praktično odstranil, a povečal na Kumljanskem ter v širšem regionalnem in medregionalnem območju (Špes, 1998).

Ker je dolinsko-kotlinsko, pokrajinsko-degradacijsko območje Zasavja tudi območje z zelo omejenimi sklenjenimi ravnimi površinami (z delno izjemo urbanega območja Litije), predstavlja prekomerno onesnaženo okolje enega izmed ključnih omejitvenih razvojnih dejavnikov. Okoljska sanacija regije je torej eden od temeljnih razvojnih izzivov do leta 2006. Vključno s sanacijo TE Trbovlje, ki je glede na obseg in večplastnost negativnih učinkov na številne pokrajinotvorne sestavine, pokrajinsko rabo (kmetijstvo, gozdarstvo), vodno oskrbo, zdravstveno tveganje in tudi z onesnaževanjem ozračja na velike razdalje kljub omejenem obdobju predvidenega obratovanja $\mathrm{z}$ okoljskozdravstvenega vidika ena od ključnih okoljskih kurativnih nalog. Kiotski sporazum prinaša tudi za Zasavsko regijo izziv zmanjševanja emisij toplogrednih plinov, zlasti $\mathrm{CO}_{2}$.

Temeljni okoljski in prostorski problemi Zasavja, ki so ena od osnov tudi za določitev regionalnih razvojnih prioritet in projektov RRP do leta 2006, so naslednji:

1. številna stara bremena okolja premogovništva, energetike, industrije in poselitve;

2. zgostitev prebivalstva in dejavnosti ter različnih emisij v zelo ozkih stranskih dolinah z omejenimi samočistilnimi zmogljivostmi;

3. pomanjkanje ravnega, nepozidanega prostora za širjenje razvojnih con in komunalno-okoljske infrastrukture (npr. čistilnih naprav) ter hkrati velik delež degradiranih rudniških in drugih površin v ravnem svetu; 
4. prekomerna onesnaženost zraka, zlasti v ožjem imisijskem območju TET in tudi v mestih (povečevanje prometnih emisij in hrupa);

5. prekomerno onesnaženje Save in zlasti njenih zasavskih pritokov ter skromen delež čiščenja komunalnih in industrijskih odpadnih vod;

6. neustrezna kakovost pitne vode, zlasti velik delež mikrobiološko neustreznih vzorcev pitne vode $\mathrm{v}$ regionalno pomembnih črpališčih;

7. prekomerna vsebnost težkih kovin v prsti, rastlinah in tkivih divjadi;

8. nerešena regionalna problematika sodobnega ravnanja in odlaganja komunalnih odpadkov;

9. slaba kakovost cestne in železniške infrastrukture.

\section{GEOGRAFSKE ZASNOVE OKOLJEVARSTVENIH PODPROGRAMOV RAZVOJNE PRENOVE ZASAVJA}

V pokrajinsko degradirani regiji je izboljšanje stanja okolja in regionalni gospodarski napredek v okviru nosilnih zmogljivosti okolja in prostora temeljni razvojno-okoljsko zasnovan cilj razvojne strategije (Regionalni razvojni 2002):

T.i. SWOT analiza prednosti, priložnosti, slabosti in nevarnosti Zasavske regije z okoljevarstvenega vidika podčrtuje kot upoštevanja vredno slabost tudi mikroregionalno zelo izrazito pokrajinsko degradiranost in izčrpanost nekaterih naravnih virov, na drugi pa prednost policentrične strnjene dolinske poselitve (cenejši kurativni okoljski ukrepi) in velike površine degradiranih premogovnih in drugih zemljišč kot potencialnih razvojnih površin po okoljski sanaciji (Preglednica 2).

Okoljske in prostorske dimenzije regionalnega razvojnega programa so zlasti prisotne $\mathrm{v}$ programu okolje in prostor kot enemu od treh glavnih razvojnih programov. Izboljšanje kakovosti bivanja obsega naslednjih sedem podprogramov RRP (Preglednica 3) (Regionalni razvojni...2002): okoljska sanacija TE Trbovlje, regionalni sistem oskrbe z zemeljskim plinom, sistem regionalno zasnovanega ravnanja s komunalnimi odpadki, gradnja osrednjih čistilnih naprav in kanalizacijskih sistemov, izboljšanje kakovosti pitne vode regionalno pomembnih črpališč, regionalno zasnovana sanacija degradiranih zemljišč ter izboljšanje regionalne prometne in telekomunikacijske infrastrukture. Med gospodarskimi programi pa je pretežno geografsko (prostorsko) zasnovan tudi razvojni podprogram novih obrtno-industrijskih in ostalih površine (con), neposredno povezan z gospodarstvom. 
Preglednica 2: Okoljska SWOT analiza Zasavja

\begin{tabular}{|c|c|c|c|c|}
\hline $\begin{array}{l}\text { Problemski } \\
\text { sklop }\end{array}$ & $\begin{array}{c}\text { Gospodarska } \\
\text { struktura }\end{array}$ & Poselitveni vzorec & Infrastruktura & $\begin{array}{l}\text { Naravni viri } \\
\text { (surovine, } \\
\text { okolje, narava, } \\
\text { prostor) }\end{array}$ \\
\hline Prednosti & $\begin{array}{l}\text { Regionalno } \\
\text { policentrična } \\
\text { razmestitev } \\
\text { nosilcev } \\
\text { gospodarstva }\end{array}$ & $\begin{array}{l}\text { Prevlada strnjenega } \\
\text { urbanega poselit- } \\
\text { venega vzorca v } \\
\text { dolinah (z izjemo } \\
\text { območja Litija- } \\
\text { Šmartno in delno } \\
\text { Radeč ter doline Save } \\
\text { od Litije do Jevnice) }\end{array}$ & $\begin{array}{l}\text { Prisotnost } \\
\text { različnih oblik } \\
\text { prometne, ener- } \\
\text { getske in drugih } \\
\text { infrastrukturnih } \\
\text { mrež }\end{array}$ & $\begin{array}{l}\text { Skromnejša } \\
\text { raba nekaterih } \\
\text { domačih virov } \\
\text { (gozd, vodni viri, } \\
\text { minerali, rekrea- } \\
\text { cijski pokrajinski } \\
\text { potenciali) }\end{array}$ \\
\hline Priložnosti & $\begin{array}{l}\text { Razvojno, } \\
\text { socialno in } \\
\text { okoljsko } \\
\text { pogojena } \\
\text { nujnost pre- } \\
\text { strukturiranja }\end{array}$ & $\begin{array}{l}\text { Cenejše nameščanje } \\
\text { okoljske (komunalne) } \\
\text { infrastrukture }\end{array}$ & $\begin{array}{l}\text { Posodobitev cest- } \\
\text { nih in železniških } \\
\text { povezav; večja } \\
\text { vloga železniške } \\
\text { infrastrukture, } \\
\text { daljinskega } \\
\text { ogrevanja, plino- } \\
\text { voda itd., } \\
\text { priključitev na AC } \\
\text { omrežje (Trojane) }\end{array}$ & $\begin{array}{l}\text { Raba endogenih } \\
\text { naravnih virov - } \\
\text { vodni viri, gozd, } \\
\text { minerali, pokra- } \\
\text { jinska pestrost }\end{array}$ \\
\hline Slabosti & $\begin{array}{l}\text { Gospodarska } \\
\text { monostruk- } \\
\text { turnost; } \\
\text { snovno - } \\
\text { energetska in } \\
\text { prostorsko- } \\
\text { okoljska } \\
\text { intenzivnost } \\
\text { gospodarstva }\end{array}$ & $\begin{array}{l}\text { Prekomerna onesna- } \\
\text { ženost urbanega in } \\
\text { delno podeželskega } \\
\text { okolja }\end{array}$ & $\begin{array}{l}\text { Slaba kakovost } \\
\text { regionalnega } \\
\text { cestnega omrežja } \\
\text { in upad javnega } \\
\text { prometa, zgostitev } \\
\text { cestnega prometa } \\
\text { v občinskih } \\
\text { središčih }\end{array}$ & $\begin{array}{l}\text { Kritična } \\
\text { obremenjenost } \\
\text { posameznih } \\
\text { pokrajinskih } \\
\text { sestavin in obmo- } \\
\text { čij }\end{array}$ \\
\hline Nevarnosti & $\begin{array}{l}\text { Gospodarsko } \\
\text { prestrukturi- } \\
\text { ranje brez } \\
\text { odprave starih } \\
\text { okoljskih } \\
\text { bremen in } \\
\text { novo obreme- } \\
\text { njevanje } \\
\text { okolja ter } \\
\text { prostora }\end{array}$ & $\begin{array}{l}\text { Prevlada suburbaniza- } \\
\text { cijskega vzorca in } \\
\text { zraščanja dolinskih } \\
\text { naselij brez ekoloških } \\
\text { koridorjev; izseljevan- } \\
\text { je hribovitega pode- } \\
\text { želja in opuščanje } \\
\text { kulturne pokrajine }\end{array}$ & $\begin{array}{l}\text { Enostranska } \\
\text { naslonitev na } \\
\text { cestno infrastruk- } \\
\text { turo }\end{array}$ & $\begin{array}{l}\text { Prekomerna raba } \\
\text { prostora in narav- } \\
\text { nih virov, preko- } \\
\text { merne emisije v } \\
\text { občutljivih ekosi- } \\
\text { stemih }\end{array}$ \\
\hline
\end{tabular}

Vir: Regionalni razvojni program za Zasavje, 2002 
Geografske zasnove sonaravnega načrtovanja regionalnega napredka Zasavske regije

Preglednica 3: Okoljski projekti regionalnega razvojnega programa Zasavske regije

\begin{tabular}{|c|c|}
\hline $\begin{array}{l}\text { Okoljski podprogrami } \\
\text { RRR Zasavje(do l. 2006) }\end{array}$ & Namen, cilji, ukrepi \\
\hline $\begin{array}{l}\text { 1. okoljska sanacija } \\
\text { TE Trbovlje }\end{array}$ & $\begin{array}{l}\text { - } \quad \text { zmanjšanje emisij (razžvepljevalna naprava) in nadalje- } \\
\text { vanje okoljevarstveno sprejemljive energetske dejavno- } \\
\text { sti v regiji }\end{array}$ \\
\hline $\begin{array}{l}\text { 2. } \begin{array}{l}\text { regionalni sistem } \\
\text { oskrbe z zem. plinom }\end{array}\end{array}$ & $\begin{array}{l}\text { prostorska razširitev in regionalna povezava ločenih } \\
\text { plinovodnih omrežij in zgostitev plinovodnega omrežja }\end{array}$ \\
\hline $\begin{array}{l}\text { 3. } \\
\text { zastem regionalno } \\
\text { s komunalnimi } \\
\text { odpadki }\end{array}$ & 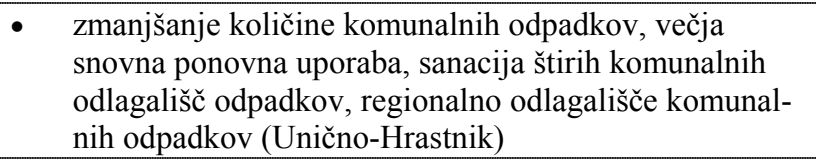 \\
\hline $\begin{array}{l}\text { 4. gradnja osrednjih } \\
\text { čistilnih naprav in } \\
\text { kanalizacijskih siste- } \\
\text { mov }\end{array}$ & $\begin{array}{l}\text { - } \quad \text { gradnja komunalnih čistilnih naprav v Litiji } \\
\text { (s Šmartnim pri Litiji)-6600 PE, Zagorju (s Kisovcem)- } \\
15000 \text { PE, na Izlakah } 3000 \text { PE, v Trbovljah-22 000 PE, } \\
\text { Hrastniku-15 000 PE in Radečah-5000 PE }\end{array}$ \\
\hline $\begin{array}{l}\text { 5. izboljšanje kakovosti } \\
\text { pitne vode regionalno } \\
\text { pomembnih črpališč }\end{array}$ & $\begin{array}{l}\text { - } \\
\text { onatančen kataster dejanskih in potencialnih virov } \\
\text { (15 večjih črpališč), ocena pokrajinske obremenjenosti } \\
\text { (poselitev, novogradnje, odpadne vode gospodinjstev } \\
\text { in živinoreje, odlaganje odpadkov, ceste itd.) in spreje- } \\
\text { mljivosti črpanja vode, določitev vodovarstvenih pasov } \\
\text { in vodovarstvenih režimov zaledij vseh regionalno po- } \\
\text { membnih črpališč }\end{array}$ \\
\hline 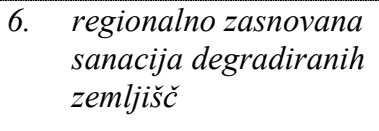 & $\begin{array}{l}\text { okoljska sar } \\
\text { industrijskil } \\
\text { razvojne in }\end{array}$ \\
\hline $\begin{array}{l}\text { 7. izboljšanje } \\
\text { regionalne prometne } \\
\text { in telekomunikacijske } \\
\text { infrastrukture }\end{array}$ & $\begin{array}{l}\text { posodobitev zasavske ceste Kresnice-Litija-Zagorje- } \\
\text { Trbovlje-Hrastnik-Radeče, priključitev na 5. evropski } \\
\text { cestni prometni koridor pri Trojanah, posodobitev } \\
\text { povezave z 10. evropskim cestnim prometnim koridor- } \\
\text { jem na območju občine Litija, posodobitev železniške } \\
\text { proge Ljubljana-Litija-Zidani Most-Dobova, dokončan- } \\
\text { je gradnje omrežja optičnih kablov in central. }\end{array}$ \\
\hline
\end{tabular}

Vir: Regionalni razvojni program za Zasavje, 2002

Okoljsko-kurativno in razvojno je ključen in finančno najbolj zahteven podprogram RRP okoljska sanacija TE Trbovlje-zmanjšanje emisij in nadaljevanje okoljevarstveno sprejemljive energetske dejavnosti v regiji. Cilj je zmanjšanje elektrarniških emisij (zlasti $\mathrm{SO}_{2}$ ) in okoljevarstveno optimalna proizvodnja energije v okviru zmogljivosti lokalnega okolja, gradnja razžvepljevalne naprave TE Trbovlje pa temeljni kurativni okoljski projekt. 
Zakon o postopnem zapiranju Rudnika Trbovlje - Hrastnik in razvojnem prestrukturiranju regije nalaga TE Trbovlje, da v obdobju do leta 2007 porabi 600000 ton premoga na leto in hkrati ne presega zakonsko določenih vplivov na okolje. Glede na analize in ekonomske izračune v Sanacijskem programu TE Trbovlje je energetsko učinkovita in $\mathrm{v}$ primeru nadaljevanja energetske dejavnosti po letu 2007 ekonomsko upravičena izgradnja razžvepljevalne naprave v vrednosti okoli 3,9 milijarde SIT. Zagotovila se naj bi v ceni električne energije in s krediti. Izgradnja razžvepljevalne naprave je torej ekonomsko optimalna le v primeru, da bo tudi po letu 2007 omogočala nadaljevanje okoljsko primerne energetske dejavnosti na osnovi uporabe tehnologije razžvepljevanja primernega uvoženega premoga. Odprto je eno izmed ključnih vprašanj, ki je povezano $s$ širšo zasnovo energetske politike Slovenije umeščanje obratovanja TE Trbovlje (npr. $\mathrm{z}$ rabo zemeljskega plina) v uresničevanje Kiotskega sporazuma o zmanjševanju emisij toplogrednih plinov. Prav tako je odprto vprašanje ekonomičnosti TE Trbovlje ob pričakovanih presežkih električne energije v Evropi (Tomšič, 2002).

Zlasti glede na zahteve sprejetega Zakona o postopnem zapiranju Rudnika Trbovlje - Hrastnik in razvojnega prestrukturiranja regije ni bila obravnavana varianta uporabe zemeljskega plina kot alternativnega energijskega vira za TE Trbovlje, čeprav je z vidika načel radikalnejše inačice trajnostno sonaravnega energetskega razvoja primernejša. Nekateri okoljevarstveni energetiki pa zagovarjajo radikalen prehod $\mathrm{k}$ učinkoviti rabi energije in obnovljivim virom (Tomšič, 2002).

Zaradi pomanjkanja odprtega prostora za lokacijo razvojnih dejavnosti $\mathrm{v}$ dolinah je prostorsko, okoljsko in razvojno ključen podprogram RRP regionalno zasnovana sanacija degradiranih zemljišč. Z okoljsko sanacijo premogovniških, opuščenih industrijskih in drugih degradiranih zemljišč naj bi Zasavje pridobilo zemljišča za novo razvojno in varovalno rabo. Ozemlje občin Zagorje, Trbovlje in Hrastnik označuje veliko pomanjkanje ravnih, nepozidanih površin, hkrati pa je značilen zelo visok delež degradiranih zemljišč, zlasti zaradi dolgotrajnega izkopavanja premoga. Pridobivalni prostor zasavskih premogovnikov oziroma rušnih con obsega okoli 1500 ha. V teh conah je prišlo do usedanja oziroma ugrezanja zemljišča ter opuščanja pokrajinske rabe. Degradirane premogovniške in druge površine (npr. kamnolomi, opuščena industrijska in druga območja) so $\mathrm{v}$ neposredni bližini urbanega prostora. Zaradi velikega pomanjkanja primernih razvojnih in varovalnih površin $\mathrm{v}$ bližini mest predstavljajo pomemben razvojno - varovalni potencial, celovita (finančno zahtevna) okoljska sanacija pa je pogoj za njihovo ponovno aktivno vlogo. Okoljska sanacija pridobivalnega prostora Zagorje je v zaključni fazi, Trbovlje-Hrastnik pa v začetni fazi. 


\section{SKLEPI}

V sonaravnem modelu regionalnega napredka omogoča celostno zasnovan geografski razvojno-varovalni pristop pretehtano načrtovanje pokrajinske rabe, gospodarskega razvoja in poselitve $\mathrm{v}$ okviru pokrajinskih omejitev. V pokrajinsko večplastno in močno degradiranih regijah je celovita sanacija geografskega okolja predpogoj dolgoročno uspešne razvojne regionalne prenove.

V Zasavju je torej potrebno razvojno prenovo zasnovati v prvi fazi na finančno zahtevni večplastni nalogo odpravi številnih okoljskih (starih) bremen, torej s poudarkom na kurativnih ukrepih. Hkrati je potrebno nove razvojne programe Zasavja prilagoditi praviloma omejenim samočistilnim zmogljivostim, predhodno oziroma hkratno zmanjševanje obremenjevanja okolja iz obstoječih virov je predpogoj za nove razvojne programe, torej tudi okoljsko in prostorsko utemeljene in sprejemljive.

\section{Literatura:}

Environment in the European Union at the Turn of the Century, 1999: European Environmental Agency, Copenhagen.

Foissner P., 2000: Endogene Entwicklung in peripheren Regionen, Moeglichkeiten der Aktivierung endogener Potenziale in der Region Vorpommern, Raumforschung und Raumordnung 58/4, Bonn, str. 297-306.

Landschaftsrahmenplan fuer die Region Neckar-Alb, 1989: Regionalverband Neckar-Alb, Tuebingen.

Navodilo o minimalni obvezni vsebini in metodologiji priprave ter načinu spremljanja in vrednotenja regionalnega razvojnega programa, 2000: Uradni list RS št.52.

Onesnaženost okolja in naravni viri kot dejavniki razvoja $v$ Zasavski regijimodelni pristop, 2001: ERICo, Velenje.

Pečar J., Farič M., 2001: Regionalni vidiki razvoja Slovenije s poudarkom na finančnih rezultatih poslovanja gospodarskih družb v letu 1999, UMAR 8/IX, Ljubljana.

Plut D., 2002: Okoljevarstveni vidiki prostorskega razvoja Slovenije, Razprave Filozofske fakultete, Ljubljana.

Poročilo in ocena o vplivih na okolje nadomestnega objekta TET 3-zvezek1, 1998: ERICo, Velenje.

Regionalni razvojni program za Zasavje, 2002: Regionalni center za razvoj d.o.o. Zagorje.

Strateške presoje vplivov regionalnih razvojnih programov na okolje in programi Strukturnih skladov Evropske unije (prevod), 2000: EU komisija, Generalni direktorat za okolje, REC, Ljubljana. 
Špes M., 1998: Degradacija okolja kot dejavnik diferenciacije urbane pokrajine, Geographica Slovenica 30, Ljubljana.

Tomšič M.G., 2002: Na poti k trajnostnemu razvoju, Znanost-priloga Dela, Ljubljana, str. 10-11.

Vrišer I., 1963: Rudarska mesta Zagorje, Trbovlje in Hrastnik, Slovenska matica, Ljubljana.

\title{
GEOGRAPHICAL BASELINES OF SUSTAINABLE PLANNING THE REGIONAL DEVELOPMENT OF ZASAVJE REGION
}

\begin{abstract}
Summary
The region of Zasavje as a whole ranks among the areas of subalpine Slovenia that have been traditionally burdened by industry, mining and energy sector. It is marked with an old industrial structure, low percentage of agrarian population, high unemployment rate, and processes of landscape degradation. The entire regional development of the past fifty years was markedly characteristic of exploiting the basic natural resource in the region, brown coal, and developing the manufacturing industry. By numerous regional and municipal pollution indicators for individual environmental components that also result from the long-lastingness of environmental pollution, the critical loads of this area rank Zasavje among the regions with the heaviest landscape degradation in Slovenia in the 1975-2000 period. Of the 12 Slovenian statistical regions, it is one of the most heavily landscape-affected and polluted ones, with the longlasting and intensive multi-level pressures on the environment. As to comparable indicators of the 1990s, the rivers and air in Zasavje were still among the most polluted, and vegetation quite heavily damaged, too, even in this period. Landscape-, health- and economy related effects of the long-lasting pollution of air, water resources, soil and other landscape forming elements already endanger the developmental capacity of the region; namely, healthy dwelling environment and well preserved and vital natural resources in the region are ever more decisive locational factors for development. The environment is more heavily polluted in Zasavje than anywhere in Slovenia, its two biggest sources of pollution being industry and energy sector. Thus, typical here is the double structure of landscape degradation: on the one hand, excessive pollution affects a smaller part only of Zasavje, but on the other, these polluted areas are precisely the essential part in view of settling and development in all the discussed municipalities.
\end{abstract}


The limited self-purifying capacities of the population-and-economyrelated most vital parts of the region are not sufficient to neutralize the multilevel effects of diverse emissions, waste waters and other pressures on the environment, particularly those of mining, energy sector, industry, transport and settlements. The anthropogenic changes in mining areas and the buildingup of open areas in the valleys of Zasavje have further reduced their selfpurifying capacities. However, the greatest disbalance in the region, between the limited self-purifying capacities and the magnitude of pressures on landscape-forming components occurs in the narrow valleys of Zasavje and Litijska kotlina basin. In contrast to most of the other Slovenian regions Zasavje is typical, in addition to high degree of local environmental pollution, also of heavy old environmental loads which are nowadays manifest primarily in a rather large proportion of degraded mining and abandoned industrial areas, tailings fields and other dumps of diverse wastes, damaged vegetation, excessive loads of heavy metals in soil, plants and wildlife, poor quality of drinking water due to endangered hydrogeographical catchment areas of the regionally and locally important pumping stations for drinking water, etc.

Thus, environmental remediation of the region is one of the key developmental issues to be solved by the year 2006, including the remediation of Trbovlje thermal power plant, notwithstanding the limited period of its projected operation. Because of the magnitude and multi-levelness of its negative impacts on numerous landscape-forming components, landscape use (agriculture, forestry), water supply, health hazard and long-distance pollution as well, the remediation of the plant is one of the essential environmental curative measures from the aspect of environment and health. For Zasavje region, too, the Kyoto agreement represents a challenge to the reduction of emissions of greenhouse gases, $\mathrm{CO}_{2}$ in particular.

The main environmental and spatial problems of Zasavje which also make a baseline for determining the regional developmental priorities dependent on the geographical conditions, and projects in the implementation plan of the Regional Development Program until 2006, are as follows:

1. numerous old environmental loads of mining, energy sector, industry, settlements and increased transport pressures;

2. concentration of the population and activities and diverse emissions in the narrow tributary valleys of limited self-purifying capacities;

3. lack of building-free areas for the spread of developmental zones and environmental public utility infrastructure (e.g. treatment plants) in urban ecosystems and a high percentage of degraded mining and other areas in the level world;

4. excessive air pollution, particularly in the narrow zone of critical loads of Trbovlje thermal power plant, and also in towns; 
5. excessive pollution of the Sava, and its tributaries in Zasavje in particular, and a low percentage of treated urban and industrial waste waters;

6. poor quality of drinking water, especially a high percentage of microbiologically polluted samples of drinking water from the regionally important pumping stations;

7. excessive loads of heavy metals in soil, plants and tissues of wild animals:

8. unsolved regional problems of contemporary managing and dumping urban waste;

9. low quality of the road infrastructure.

Environmental and spatial dimensions of the regional development program are particularly considered in one of the three main development programs. Improvement of dwelling quality includes the following subprograms: ecological remediation of Trbovlje thermal power plant - reduction of emissions and continuation of environmentally acceptable power generation in the region; regional system of natural gas supply; regionally planned system of urban waste management; construction of central treatment plants and collecting systems; improvement of drinking water quality of regionally important pumping stations; regionally planned remediation of degraded lands; improvement of regional transport- and telecommunication infrastructures. Environmentally and spatially important project within the scope of economy is the project on new industrial-crafting and other zones which should mainly be arranged on the locations of degraded or abandoned (mining and industrial) zones. 